\title{
Molecular Cloning of Human Synovial Cell Collagenase and Selection of a Single Gene from Genomic DNA
}

\author{
Constance E. Brinckerhoff, Peggy L. Ruby, Scott D. Austin, M. Elizabeth Fini, and Hillary D. White
}

Department of Medicine, Dartmouth Medical School, Hanover, New Hampshire 03756

\begin{abstract}
We used a subclone of a rabbit genomic clone for collagenase that cross-hybridizes with human synovial cell messenger RNA (mRNA) to identify a human collagenase complementary DNA (cDNA) clone. The human cDNA clone is 2.1 kilobases (kb) and selects a mRNA transcript of approximately the same size from primary cultures of rheumatoid synovial cells that produce collagenase, but no mRNA is selected from control (nonproducing) synovial fibroblasts. Restriction enzyme analysis and DNA sequence data indicate that our cDNA clone is full length and that it is identical to that recently described for human skin fibroblast collagenase. The cDNA clone identified a single collagenase gene of $\sim 17 \mathrm{~kb}$ from blots of human genomic DNA. The identity of human skin and synovial cell collagenase and the ubiquity of this enzyme and of its substrates, the interstitial collagens types I, II, and III, imply that common mechanisms controlling collagenolysis throughout the human body may be operative in both normal and disease states.
\end{abstract}

\section{Introduction}

The neutral proteinase collagenase (E.C. 3.4 .23 .7 ) is the only enzyme able to initiate breakdown of the interstitial collagens, types I, II, and III (see reviews [1, 2]). The fact that these collagens are the body's most abundant proteins means that collagenase plays a key role in the remodeling of collagen that occurs constantly in both normal and diseased conditions. Thus, mechanisms concerning the regulation of collagenase both at the level of protein biochemistry and at the level of the gene are of prime importance to our understanding of connective tissue metabolism.

Rheumatoid arthritis is a connective tissue disease in which collagenase is a major mediator of pathology (3). In rheumatoid arthritis, synovial cells lining the joint proliferate into a huge mass which secretes large quantities of collagenase and invades and destroys cartilage, tendon, and bone. Normally, these cells synthesize and secrete only minimal amounts of collagenase, but in the disease state, they are stimulated by phagocytosis (4), cell fusion (5), and mediators such as interleukin $1(6,7)$ and crystals of monosodium urate monohydrate $(8)$ to produce large quantities of enzyme. Here we develop and characterize a complementary DNA (cDNA) clone for human synovial cell collagenase. We show that this cDNA clone cross-hybridizes with

Address reprint requests to Dr. Brinckerhoff.

Received for publication 4 August 1986 and in revised form 24 September 1986

J. Clin. Invest.

(C) The American Society for Clinical Investigation, Inc. 0021-9738/87/02/0542/05 \$1.00

Volume 79, February 1987, 542-546 rabbit collagenase messenger RNA (mRNA) and is identical to a cDNA for human skin collagenase. We further use this cDNA clone to provide data consistent with the existence of a single collagenase gene in the human genome.

\section{Methods}

Cell culture. Specimens of rheumatoid synovial tissue, obtained from the operating room of the Mary Hitchcock Hospital (Hanover, NH), were dissociated into a single-cell suspension by sequential treatment with bacterial collagenase and trypsin (9). Cells were plated at $50 \%$ confluency in 100-mm diam culture dishes in $20 \%$ fetal calf serum (Gibco, Grand Island, NY). After 7-10 d, when the cells had become confluent, they were washed three times with Hanks' balanced salt solution and placed in serum-free medium supplemented with $0.2 \%$ lactalbumin hydrolysate. In some experiments, primary cultures were trypsinized $(0.25 \%$; Gibco) and passaged in Dulbecco's modified Eagle's medium with $10 \%$ fetal calf serum. At confluence, they were also transferred to serum-free medium. In contrast to primary cultures of rheumatoid synovial cells, these cells do not make collagenase (9) and hence, they served as a negative control. After $24-48 \mathrm{~h}$ in serum-free conditions, medium was assayed for collagenase activity in a standard fibril assay with $\left[{ }^{14} \mathrm{C}\right]$ collagen fibrils (10-12) and the RNA was harvested as described previously $(13,14)$

Construction and screening of a human synovial cell cDNA library for collagenase in bacteriophage $\lambda$-gt11. RNA was harvested from primary cultures of rheumatoid synovial cells derived from three individuals. Cells were cultured in serum-free medium and were shown to be synthesizing collagenase by means of the collagen fibril assay (see above). Poly A+ RNA was isolated by oligo dT-cellulose chromatography (13, 15). $6 \mu \mathrm{g}$ of poly A+ RNA served as a template for cDNA synthesis, carried out as described by Gubler and Hoffman (16). After ligation to linkers containing the Eco RI restriction site, the cDNA was cloned into bacteriophage $\lambda$-gt 11, purchased from Promega Biotec (Madison, WI), according to the manufacturer's instructions. A cDNA library containing $1.6 \times 10^{4}$ recombinants was generated and was amplified once.

The library was plated at $10^{4}$ recombinants per $100-\mathrm{mm}$ diam culture plate and screened for clones containing collagenase sequences by means of in situ plaque hybridization (17) using a rabbit collagenase genomic subclone, p206, known to cross-hybridize with human synovial cell mRNA (18). Duplicate plaque lifts onto Gene Screen Plus (New England Nuclear, Boston, MA) were made from each plate of recombinants and were probed with p206 insert radiolabeled with ${ }^{32} \mathrm{P}$ by the oligolabeling method of Feinberg and Vogelstein (19). Hybridizations were performed exactly as described (20).

DNA from three-time plaque-purified recombinants was prepared as described (17). Clone inserts were restriction mapped by single and multiple analysis of the products of restriction enzyme digestions on agarose gels (17)

DNA sequencing. The entire Eco RI-digested human collagenase cDNA clone, termed hu-col 16, was ligated with linearized M13mp19 vector and transfected into bacterial strain JM101 (21). A clone containing the noncoding strand of the 0.3-kb Eco RI fragment was isolated and sequenced by the dideoxynucleotide termination method (22). Multiple sequence determinations were made to ensure accuracy of analysis from this single strand.

Northern and Southern blot analysis. For Northern blot analysis, 25 $\mu \mathrm{g}$ of whole-cell RNA from collagenase-producing human synovial cells 
(i.e., primary cultures) or nonproducing cells (i.e., passaged cultures) was electrophoresed at $4^{\circ} \mathrm{C}$ in a $1 \%$ agarose gel containing $2.2 \mathrm{M}$ formaldehyde and transferred to Gene Screen Plus $(17,20)$. RNA was harvested from rabbit synovial cells that had been induced to synthesize collagenase by treatment with $10^{-8} \mathrm{M}$ phorbol myristate acetate (13). The blot was probed first with the hu-col $16 \mathrm{cDNA}$ radiolabeled with ${ }^{32} \mathrm{P}$ by nick translation (17). The blot was then stripped by boiling for $10^{\prime}$ in 0.1 $X$ standard saline citrate and the effectiveness of the stripping procedure was checked by an overnight exposure with XAR-5 film (Eastman Kodak Co., Rochester, NY). It was then probed with rabbit activator cDNA (23), which had been removed in toto from vector with Eco RI and labeled with ${ }^{32} \mathrm{P}(19)$. Hybridizations were as detailed $(17,20)$.

Human genomic DNA for Southern blot analysis was prepared from peripheral blood lymphocytes separated from freshly drawn venous blood by unit gravity sedimentation through dextran/EDTA, following the methods of Aldridge et al. (24). $10 \mu \mathrm{g}$ of each DNA sample was digested overnight at $37^{\circ} \mathrm{C}$ with appropriate enzymes (Boehringer Mannheim, Indianapolis, IN) and run into an $0.8 \%$ agarose gel with Tris/borate/ EDTA buffer (17). The electrophroresis was carried out at $70 \mathrm{~V}$ for $4 \mathrm{~h}$ at $4^{\circ} \mathrm{C}$ with recirculation of buffer. Gels were then blotted onto Gene Screen Plus as described for Southern blots. After blotting, they were probed with either the 0.3-kb Eco RI fragment, representing the $5^{\prime}$ end of the collagenase cDNA (see below), or the 1.75-kb Eco RI fragment containing the rest of the cDNA insert with its $3^{\prime}$ end. Probes were labeled by oligolabeling (19) and hybridized $(17,20)$.

\section{Results}

Identification of a cDNA clone for human synovial cell collagenase. To screen the cDNA library for a clone for human synovial cell collagenase, we took advantage of the fact that an Eco RI fragment of a rabbit genomic clone for collagenase cross-hybridized with human mRNA (18). This fragment, termed p206,
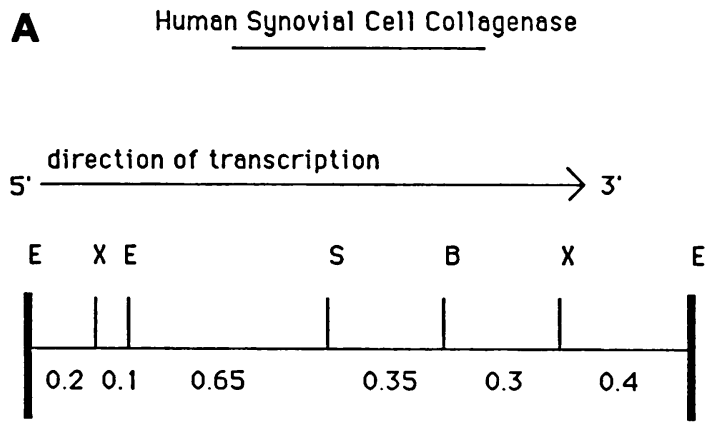

$$
\begin{aligned}
& \text { Key: } \\
& E=E C O R I \\
& X=X b \theta I \\
& S=S s t I \\
& B=B a m ~ H I
\end{aligned}
$$

\section{B $5{ }^{\prime} \ldots$ CGGCATTCCGGCAAGAGGCTGGGAAGCCATCACTTACCTTGCACTGAGAAAGAAGACAAAGGCCAGT}

ATG CAC AGC TTT CCT CCA CTG CTG CTG CTG CTG TTC TGG GGT GTG GTG TCT CAC AGC TTC met-his-ser-phe-pro-pro-leu-leu-leu-leu-leu-phe-trp-gly-val-val-ser-his-ser-phe CCA GCG ACT CTA GAA ACA CAA GAG CAA GAT GTG GAC TTA GTC CAG AAA TAC CTG GAA AAA pro-ala-thr-leu-glu-thr-gln-glu-gln-asp-val-asp-leu-val-gln-lys-tyr-leu-glu-lys

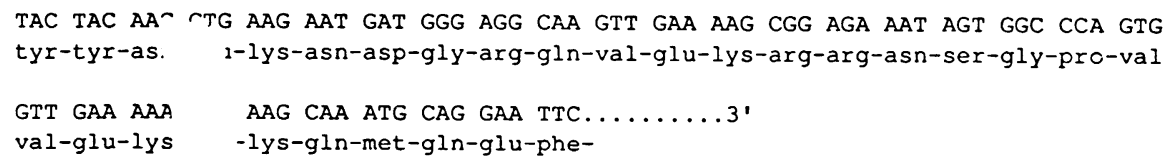



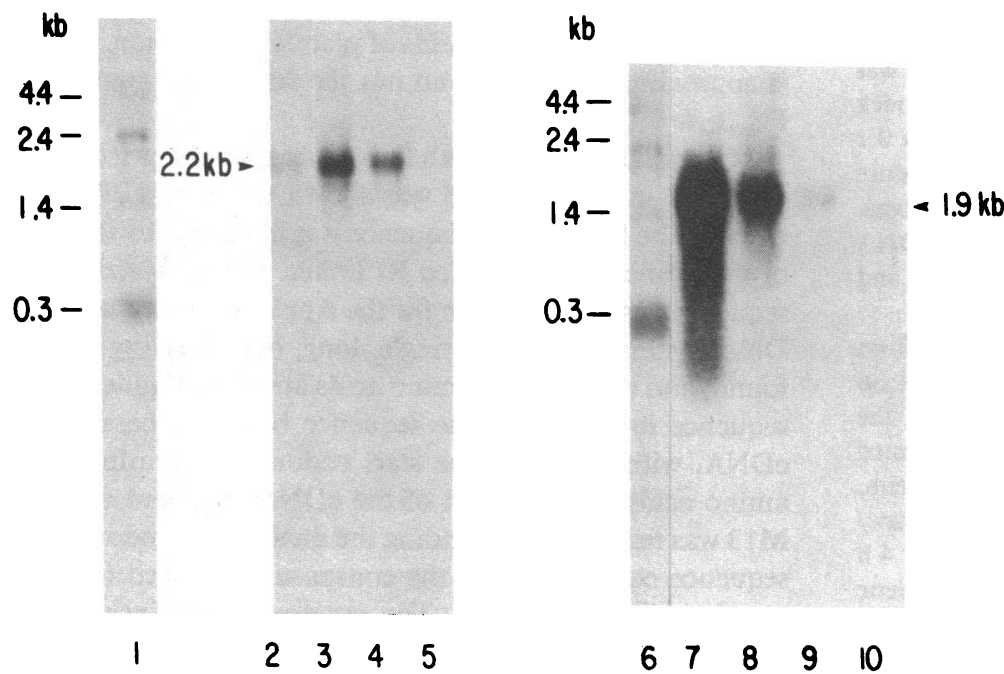

Figure 2. Northern blot analysis of human synovial cell mRNA. Whole-cell RNA was harvested from collagenase-producing human and rabbit synovial fibroblasts and from control (nonproducing) human synovial fibroblasts, electrophoresed in an agarose-formaldehyde gel, blotted onto Gene-Screen Plus and probed with ${ }^{32}$ P-labeled cDNAs. $(A)$ Probes with human collagenase cDNA. Lane 1, Bethesda Research Laboratories RNA size ladder, $5 \mu \mathrm{g}$; lane 2, rabbit RNA from collagenase-producing cells, $25 \mu \mathrm{g}$; lane 3 , human RNA from collagenase-producing cells, sample 1, 25 $\mu \mathrm{g}$; lane 4, human RNA from collagenase-producing cells, sample 2, $25 \mu \mathrm{g}$; lane 5, human RNA from control cells, $25 \mu \mathrm{g}$. (B) Probes with rabbit activator cDNA. Lane 6 , RNA size ladder, $5 \mu \mathrm{g}$; lane 7 , same as lane 2; lane 8, same as lane 3; lane 9, same as line 4; lane 10 , same as lane 5 .

collagenase cDNA also showed no differences. These data strongly suggest that the mRNA for human skin and human synovial cell collagenase were synthesized from the same gene.

Identification of human synovial cell collagenase mRNA. When lambda hu-col 16 was used to probe Northern blots, it selected a single mRNA band of $2.2 \mathrm{~kb}$ from RNA derived from primary rheumatoid synovial cells that were producing collagenase. No band was selected from RNA from control cultures of human synovial fibroblasts that were not synthesizing collagenase (Fig. $2 A$ ). Cross-hybridization between rabbit mRNA and human collagenase cDNA was also noted.

Cross-hybridization of rabbit activator $c D N A$ with human $m R N A$. We have recently isolated a full-length cDNA clone for rabbit activator, a metalloproteinase responsible for the activation of latent rabbit procollagenase $(23,29-31)$. By DNA sequence analysis (29), rabbit activator shows $77 \%$ homology to rat transin, an oncogene transformation-induced protein (32), and it is possible that transin may be the functional equivalent of activator in the rat. To determine whether a similar protein may exist in populations of rheumatoid synovial cells, we first stripped and then reprobed the Northern blot described above with rabbit activator cDNA. Fig. $2 B$ shows that rabbit activator cDNA hybridized strongly with rabbit mRNA, selecting a band of $\sim 1.9 \mathrm{~kb}$. In addition, the cDNA selected a human mRNA, also of $1.9 \mathrm{~kb}$, from primary, collagenase-producing cultures but not from noncollagenase-producing passaged cells. Note that this band is distinct from that detected by the human collagenase cDNA, but that it appears to be coordinately regulated with collagenase mRNA inasmuch as both are present in primary cultures but not in passaged ones.

Detection of the gene for human synovial cell collagenase. Human genomic DNA from 11 individuals, five of whom are members of one family, was digested with a battery of restriction enzymes, electrophoresed and blotted, and then probed with the 1.7- and 0.3-kb Eco RI fragments of lambda hu-col 16 cDNA clone. Fig. 3 shows one example of our studies in which genomic DNA from all 11 individuals was digested with Eco RI and probed with the $1.75-\mathrm{kb}$ fragment of the hu-col $16 \mathrm{cDNA}$ clone. This probe detected 15- and 1.7-kb fragments in all individuals.

In individual 7 , two additional fragments of 1.1 and $0.6 \mathrm{~kb}$ were also present. When the blot was probed with the $0.3-\mathrm{kb}$ cDNA fragment, a band of $\sim 0.3 \mathrm{~kb}$ was detected in all samples (data not shown). In that these bands add up to $17 \mathrm{~kb}$, it is tempting to hypothesize that individual 7 has two collagenase alleles, one with an additional Eco RI site within the 1.7-kb fragment. Digestion of genomic DNA from these same individuals with SstI revealed the presence of fragments of 15 and $2.2 \mathrm{~kb}$ whereas digestion with Bam gave fragments of 10.9 and $6 \mathrm{~kb}$. These data

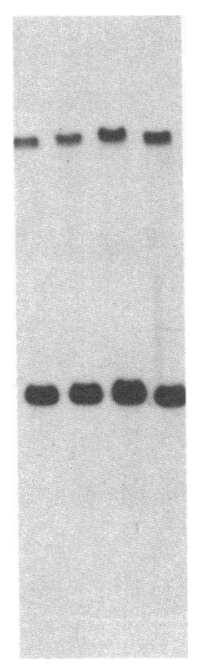

11 1098

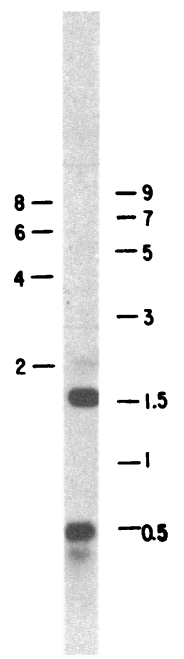

std

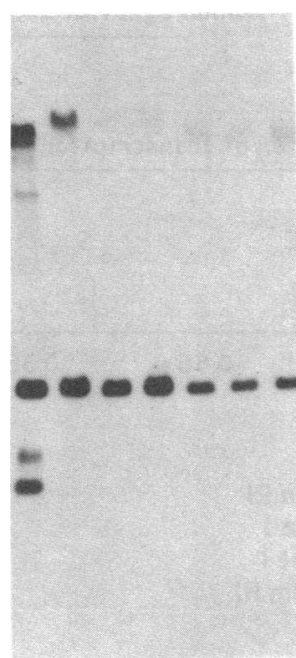

$\begin{array}{lllllll}7 & 6 & 5 & 4 & 3 & 2 & 1\end{array}$ $\sim 15 \mathrm{~kb}$

$1.7 \mathrm{~kb}$

$1.1 \mathrm{~kb}$

$0.6 \mathrm{~kb}$

Figure 3. Southern blot analysis of human genomic DNA probed with human collagenase cDNA. $10 \mu \mathrm{g}$ of genomic DNA was digested with Eco RI, electrophoresed in $\mathbf{0 . 8 \%}$ agarose, blotted onto Gene Screen Plus, and then probed with ${ }^{32}$ P-labeled 1.75 Eco RI fragment of hu-col 16 cDNA. Lanes 7-11 represent DNA taken from members of one family. Lanes 7 and 8 contain DNA from the parents, and lane 7 contains the DNA from an individual heterozygous for an Eco RI allelic fragment. 
are consistent with the hypothesis that there is a single gene of $\sim 17 \mathrm{~kb}$ for collagenase.

\section{Discussion}

Data amassed over the years have supported the concept that human skin and synovial cell collagenase are related enzymes. Synthesis of both can be induced (1-7, 33) and suppressed (34$36)$ by the same compounds. Both have similar molecular weights $(28,37,38)$. Both are secreted as latent forms that are activated by proteinases and organic mercurials and inactivated by nonspecific and specific metalloproteinase inhibitors $(1,2)$. Furthermore, recent evidence points to similar if not identical collagenases isolated from a variety of fibroblasts, including corneal (39), gingival (40), and skin $(37,38)$, as well as from several types of endothelial cells, such as brain capillary (41) and umbilical vein (42). However, these collagenases may be distinct from the neutrophil collagenase (43) and from rat uterine collagenase $(44,45)$, which may be under different control mechanisms, and from type IV collagenase which exhibits different substrate specificity (46). In this article we show, by restriction enzyme analysis and by limited DNA sequence, that there are no differences between synovial cell and skin fibroblast collagenase mRNAs, even in the $5^{\prime}$ and $3^{\prime}$ untranslated regions where there is less selective pressure for sequence conservation (47). We believe, therefore, that this constitutes exceedingly solid evidence that the two cDNAs are the product of the same gene.

Of interest is the fact that we have detected a single gene for synovial cell/skin collagenase and that this gene appears to show allelic variation. In the future it will be important to determine whether the collagenase gene in certain individuals with particularly erosive rheumatoid arthritis or individuals with recessive dystrophic epidermolysis bullosa, a disease of the skin in which excess collagenase production is pathologically important (48), contains restriction fragment length polymorphisms.

The confirmation of the identity at the level of nucleic acid of human skin and synovial cell collagenase both solidifies our previous biochemical knowledge and suggests important implications about the ubiquity of mechanisms regulating connective tissue metabolism throughout the body. Collagenases can be regulated by a variety of mechanisms. First, enzymatic activity of active collagenase can be inhibited by such nonspecific inhibitors of enzymes such as $\alpha_{2}$-macroglobulin, or by specific inhibitors of metalloproteinases, such as tissue inhibitor of metalloproteinases (TIMP); both are ubiquitous (see reviews $[1,2])$.

A second controlling point for regulation of collagenase activity is in the enzymatic activation of latent procollagenase by another metalloproteinase, proactivator $(30,31)$. At least in the rabbit synovial cell system, conversion of procollagenase to an enzymatically active form requires the presence of an activator protein, which is, itself, secreted in latent form. Activation of procollagenase depends, therefore, on a mini-cascade: the sequential activation of proactivator (by enzymes such as trypsin) which then, in turn, activates latent procollagenase. The human analogue of activator has not yet been documented although we have detected a $1.9-\mathrm{kb}$ transcript in human synovial cell mRNA probed with rabbit activator cDNA (Fig. $2 B$ ). In addition, Okada et al. (49) have isolated three metalloproteinases from conditioned culture medium derived from human synovial cells and one or more of these may be candidates for the human activator protein(s).
A final control point for regulation of collagenase activity is at the level of biosynthesis. Synthesis of collagenase can be induced by a variety of agents, such as interleukin $1(6,7)$, phorbol esters (13), crystals of monosodium urate monohydrate (8) or polyethylene glycol which induces giant-cell formation (5). Conversely, biosynthesis can be antagonized by two classes of compounds, the corticosteroids and the retinoids (34-36), as well as by an autocrine (50). Recent data indicate first, that regulation occurs at the level of mRNA synthesis (13) and second, that activator and collagenase are both coordinately induced and suppressed (23). Thus we can begin to establish a family of metalloproteinases that appear coordinately regulated and may play a critical role in the modulation of connective tissues.

\section{Acknowledgments}

We thank the Section of Orthopedic Surgery at the Dartmouth-Hitchcock Medical Center for kindly supplying us with specimens of rheumatoid synovial tissue.

This study was supported by grants from the U. S. Public Health Service (AR-26599), the New Hampshire and National Chapters of the Arthritis Foundation, Applied DNA Systems, Inc. (Pittsburgh, PA), and The RGK Foundation (Austin, TX).

\section{References}

1. Woolley, D. E., and J. M. Evanson. 1980. Collagenase in Normal and Pathological Connective Tissues. John Wiley and Sons, New York.

2. Harris, E. D., Jr., H. G. Welgus, and S. M. Krane. 1984. Regulation of the mammalian collagenases. Coll. Rel. Res. 4:493-512.

3. Harris, E. D., Jr. 1985. Pathogenesis of rheumatoid arthritis. In Textbook of Rheumatology. W. N. Kelley, E. D. Harris, Jr., S. Ruddy, and C. B. Sledge, editors. W. B. Saunders Co., Philadelphia. 886-914.

4. Werb, Z., and J. J. Reynolds. 1974. Stimulation by endocytosis of the secretion of collagenase and neutral proteinase from rabbit synovial fibroblasts. J. Exp. Med. 140:1482-1497.

5. Brinckerhoff, C. E., and E. D. Harris, Jr. 1978. Collagenase production by cultures containing multinucleated cells derived from synovial fibroblasts. Arthritis Rheum. 21:745-753.

6. Mizel, S. B., J.-M. Dayer, S. M. Krane, and S. E. Mergenhagen. 1981. Stimulation of rheumatoid synovial cell collagenase and prostaglandin production by partially purified lymphocyte-activating factor (interleukin-1). Proc. Natl. Acad. Sci. (USA). 78:2474-2477.

7. Dayer, J.-M., B. deRochemonteix, B. Burrus, S. Demczuk, and C. A. Dinarello. 1986. Human recombinant interleukin-1 stimulates collagenase and $\mathrm{PGE}_{2}$ production by human synovial cells. J. Clin. Invest. 77:645-648.

8. Hasselbacher, P., R. M. McMillan, C. A. Vater, J. L. Hahn, and E. D. Harris, Jr. 1981. Stimulation of secretion of collagenase and prostaglandin $E_{2}$ by synovial fibroblasts in response to crystals of monosodium urate monohydrate: a model for joint destruction in gout. Trans. Assoc. Am. Phys. 94:243-252.

9. Dayer, J.-M., S. M. Krane, R. G. G. Russell, and D. R. Robinson. 1976. Production of collagenase and prostaglandins by isolated adherent synovial cells. Proc. Natl. Acad. Sci. (USA). 73:945-949.

10. Harris, E. D., Jr., D. R. DiBona, and S. M. Krane. 1969. Collagenase in synovial fluid. J. Clin. Invest. 48:2104-2113.

11. Glimcher, M. J., C. J. Francois, L. Richards, and S. M. Krane. 1964. The presence of organic phosphorus in collagens and gelatins. Biochim. Biophys. Acta. 93:585-602.

12. Gisslow, M. T., and B. C. McBride. 1975. A rapid sensitive collagenase assay. Anal. Biochem. 68:70-78.

13. Brinckerhoff, C. E., I. M. Plucinska, L. A. Sheldon, and G. T. O'Connor. 1986. Half-life of synovial cell collagenase mRNA is modulated by phorbol myristate acetate but not by all-trans-retinoic acid or dexamethasone. Biochemistry. 25:6378-6384. 
14. Chirgwin, J. M., A. E. Przybyla, R. J. MacDonald, and W. J. Rutter. 1979. Isolation of biologically active ribonucleic acid from sources enriched in ribonuclease. Biochemistry. 18:5294-5299.

15. Aviv, H., and P. Leder. 1972. Purification of biologically active globin mRNA by chromatography on oligothymidylic acid-cellulose. Proc. Natl. Acad. Sci. (USA). 69:1408-1412.

16. Gubler, U., and B. J. Hoffman. 1983. A simple and very efficient method for generating cDNA libraries. Gene. 25:263-269.

17. Maniatis, T., E. F. Fritsch, and J. Sambrook. 1982. Molecular Cloning: a Laboratory Manual. Cold Spring Harbor Laboratory Press, Cold Spring Harbor, NY.

18. Fini, M. E., S. D. Austin, P. J. Holt, P. L. Ruby, R. H. Gross, H. D. White, and C. E. Brinckerhoff. 1986. Homology between exoncontaining portions of rabbit genomic clones for synovial cell collagenase and human foreskin and synovial cell mRNAs. Coll. Rel. Res. 6:239248.

19. Feinberg, A. P., and B. Vogelstein. 1983. A technique for radiolabeling restriction fragments to high specific activity. Anal. Biochem. 132:6-13. Addendum. Anal. Biochem. 137:266-267.

20. Genescreen. Colony/ plaque screen hybridization transfer membrane. NEN Research Products, Boston, MA. Catalogue No. 978/978A.

21. Messing, J. 1983. New M13 vectors for cloning. Methods Enzymol. 101:20-78.

22. Sanger, F., S. Nicklen, and A. R. Coulsen. 1977. DNA sequencing with chain-terminating inhibitors. Proc. Natl. Acad. Sci. (USA). 74:54635467.

23. Brinckerhoff, C. E., P. L. Ruby, M. J. Karmilowicz, M. E. Fini, and S. D. Austin. 1987. Co-ordinate regulation of a family of metalloproteinases in rabbit and human synovium Arthritis Rheum. In press. (Abstr.)

24. Aldridge, J., L. Kunkel, G. Bruns, U. Taniravahi, M. Lalande, T. Brewster, E. Moreau, M. Wilson, W. Bromley, T. Roderick, and S. Latts. 1984. A strategy to reveal high frequency RFLPs along the human chromosome. Am. J. Hum. Genet. 36:546-564.

25. Gross, R. H. 1986. A DNA sequence analysis program for the Apple McIntosh. Nucleic Acid Res. 14:591-596.

26. Kozak, M. 1986. Point mutations define a sequence flanking the AUG initiator codon that modulates translation by eucaryotic ribosomes. Cell. 44:283-292.

27. Richards, R. I., J. Shine, A. Ullrich, R. E. Wells, and H. M. Goodman. 1979. Molecular cloning and sequence analysis of adult chicken $\beta$ globin cDNA. Nucleic Acid Res. 7:1137-1146.

28. Goldberg, G. L., S. M. Wilhelm, A. Kronberger, E. A. Bauer, G. A. Grant, and A. Z. Eisen. 1986. Human fibroblast collagenase. $J$. Biol. Chem. 261:6600-6605.

29. Fini, M. E., I. M. Plucinska, A. M. Beeman, and C. E. Brinckerhoff. 1987. Collagenase and its activator: members of a new super gene family of metalloproteinases which includes an onco-gene induced mRNA. Arthritis Rheum. In press. (Abstr.)

30. Vater, C. A., H. Nagase, and E. D. Harris, Jr. 1983. Purification of an endogenous activator of procollagenase from rabbit synovial fibroblast culture medium. J. Biol. Chem. 258:9374-9382.

31. Vater, C. A., H. Nagase, and E. D. Harris, Jr. 1986. Proactivatordependent activation of procollagenase induced by treatment with EGTA. Biochem. J. 237:853-858.

32. Matrisian, L. M., P. LeRoy, C. Ruhlmann, M. C. Gesnel, and R. Breathnach. 1986. Isolation of the oncogene and epidermal growth factor-induced transin gene: complex control in rat fibroblasts. Mol. Cell. Biol. 6:1679-1686.

33. Korn, J. H., C. E. Brinckerhoff, and R. L. Edwards. 1985. Synthesis of $\mathrm{PGE}_{2}$, collagenase and tissue factor by fibroblast substrains. Coll. Rel. Res. 5:437-447.

34. Brinckerhoff, C. E., R. M. McMillan, J.-M. Dayer, and E. D. Harris, Jr. 1980. Inhibition by retinoic acid of collagenase production by rheumatoid synovial cells. $N$. Engl. J. Med. 303:432-435.

35. Brinckerhoff, C. E., and E. D. Harris, Jr. 1981. Modulation by retinoic acid and corticosteroids of collagenase production by rabbit synovial fibroblasts treated with phorbol myristate acetate or polyehtylene glycol. Biochim. Biophys. Acta. 677:424-432.

36. Bauer, E. A., J. L. Seltzer, and A. L. Eisen. 1983. Inhibition of collagenase degradative enzymes by retinoic acid in vitro. J. Invest. Dermatol. 6(Suppl.):603-607.

37. McCroskery, P. A., S. A. Arai, E. P. Amento, and S. M. Krane. 1985. Stimulation of procollagenase synthesis in human rheumatoid synovial cells by mononuclear cell factor/inerleukin-1. FEBS Fed. Eur. Biochem. Soc. Lett. 191:7-12.

38. Wilhelm, S. M., A. Z. Eisen, M. Teter, S. D. Clark, A. Kronberger, and G. Goldberg. 1986. Human fibroblast collagenase: glycosylation and tissue-specific levels of enzyme synthesis. Proc. Natl. Acad. Sci. (USA). 83:3756-3760

39. Johnson-Wint, B., and J. Gross. 1984. Regulation of connective tissue collagenase production: stimulators from adult and fetal epidermal cells. J. Cell Biol. 98:90-96.

40. Golub, L. M., H. M. Lee, L. G. Lehrer, A. Nemiroff, T. F. McNamara, R. Kaplan, and N. S. Ramamurthy. 1983. Minocycline reduces gingival collagenolytic activity during diabetes. J. Periodontal Res. 18:516-526.

41. Herron, G. S., Z. Werb, K. Dwyer, and M. J. Banda. 1986. Secretion of metalloproteinases by stimulated capillary endothelial cells. J. Biol. Chem. 261:2810-2813.

42. Moscatelli, D. A., D. B. Rifkin, and E. A. Jaffe. 1985. Production of latent collagenase by human umbilical vein endothelial cells in response to angiogenic preparations. Exp. Cell Res. 156:379-390.

43. Hasty, K. A., M. S. Hibbs, A. H. Kang, and C. L. Mainardi. 1984. Heterogeneity among human collagenases demonstrated by monoclonal antibody that selectively recognizes and inhibits human neutrophil collagenase. J. Exp. Med. 159:1455-1463.

44. Roswit, W. T., J. Halne, and J. J. Jeffrey. 1983. Purification and properties of rat uterine procollagenase. Arch. Biochim. Biophys. 225: 285-295.

45. Welgus, H. G., G. A. Gant, J. C. Sacchettini, W. T. Roswit, and J. J. Jeffrey. 1985. Gelatinolytic activity of rat uterus collagenase. J. Biol. Chem. 260:13601-13606.

46. Salo, T., L. Liotta, and K. Tryggvason. 1983. Purification and characterization of a murine basement membrane collagen-degrading enzyme secreted by metastatic tumor cells. J. Biol. Chem. 258:30583063.

47. Fyrberg, E. A., J. W. Mahaffey, B. J. Bond, and N. Davidson. 1983. Transcripts of the six Drosophila actin genes accumulate in a stage and tissue specific manner. Cell. 33:115-123.

48. Stricklin, G. P., H. G. Welgus, and E. A. Bauer. 1982. Human skin collagenase in recessive dystrophic epidermylosis bullosa. J. Invest. Dermatol. 79:208-211.

49. Okada, Y., H. Nagase, and E. D. Harris, Jr. 1986. A metalloproteinase from human rheumatoid synovial fibroblasts that digests connective tissue matrix components. J. Biol. Chem. 261:14245-14255.

50. Brinckerhoff, C. E., M. C. Benoit, and W. J. Culp. 1985. Autoregulation of collagenase production by a protein synthesized and secreted by synovial fibroblasts: a cellular mechanism for control of collagen degradation. Proc. Natl. Acad. Sci. (USA). 82:1916-1920. 